\title{
Review \\ Ecophysiological Crop Modelling Combined with Genetic Analysis Is a Powerful Tool for Ideotype Design
}

Junfei Gu ${ }^{1,2}$ (D)

1 Jiangsu Key Laboratory of Crop Genetics and Physiology/Jiangsu Key Laboratory of Crop Cultivation and Physiology, Agricultural College of Yangzhou University, Yangzhou 225009, China; Gujf@yzu.edu.cn

2 Jiangsu Co-Innovation Center for Modern Production Technology of Grain Crops, Yangzhou University, Yangzhou 225009, China

\begin{abstract}
Improving the grain yield of crops in both favourable and stressful environments is the main breeding objective required to ensure food security. In this review, I outline a genotype-tophenotype approach that exploits the potential values of quantitative genetics and process-based crop modelling in developing new plant types with high yields. The effects of quantitative trait locus (QTL), for traits typically at the single-organ level over a short time scale, were projected for their impact on crop growth during the whole growing season in the field. This approach can provide more markers for selection programmes for specific environments whilst also allowing for prioritization. Crop modelling is thus a powerful tool for ideotyping under contrasting conditions, i.e., use of single-environment information for predicting phenotypes under different environments.
\end{abstract}

Keywords: crop model; genotype-environment interactions; quantitative trait locus; simulation

check for

updates

Citation: Gu, J. Ecophysiological Crop Modelling Combined with Genetic Analysis Is a Powerful Tool for Ideotype Design. Agronomy 2022, 12, 215. https://doi.org/10.3390/ agronomy12010215

Academic Editor: Carmen Galan

Received: 3 November 2021

Accepted: 14 January 2022

Published: 16 January 2022

Publisher's Note: MDPI stays neutral with regard to jurisdictional claims in published maps and institutional affiliations.

Copyright: (C) 2022 by the author. Licensee MDPI, Basel, Switzerland. This article is an open access article distributed under the terms and conditions of the Creative Commons Attribution (CC BY) license (https:// creativecommons.org/licenses/by/ $4.0 /)$.

\section{Introduction}

Crop yields have been substantially improved since the first 'Green Revolution' in the mid-1960s when the high-yield modern crop varieties of rice and wheat were developed and were subsequently adopted by farmers in Latin America and Asia. However, despite recent achievements in plant breeding and genetics, the rate of increasing crop yields is declining, and there is a need for multidisciplinary efforts towards a second green revolution [1]. Crop modelling has long been considered a useful tool that assists in breeding [2-6]. However, to date the contribution has been small $[7,8]$.

This small contribution was most likely because crop physiologists and modelers did not fully consider the genetic basis of model input parameters [9], although they often refer to these model input parameters as 'genetic coefficients' [10-12]. The development of molecular genetics provided a new approach for relating crop model input parameters to their genetic coefficients, quantitative trait loci (QTLs). However, because of the complexity of regulatory networks in plant and crop systems and given their complex interactions with the environment factors, field crops show strong genotype-environment $(\mathrm{G} \times \mathrm{E})$ interactions. This complexity is especially the case when breeding for drought tolerance. Sometimes, spectacular results obtained in one drought scenario might have limited value for improving yield in other scenarios as drought varies in intensity and timing [13]. For example, in wheat, selection for genotypes with higher transpiration efficiency (low $\Delta^{13} \mathrm{C}$ ) could improve yield by $10 \%$ in very dry environments [14], but the yield advantage could disappear under moderate stress [14], and even hamper plant growth, resulting in smaller plants with reduced transpiration, biomass and yield [15,16]. These $G \times E$ interactions always result in inconsistency of morpho-physiological traits, which make the selection criteria for breeding complex and unstable, especially under abiotic stressed environments. Therefore, it is necessary to accurately model and predict $G \times E$ interactions for improving breeding efficiency through marker-assisted selection (MAS). 


\section{Integration of Crop Physiology with Genetics-QTL-Based Modelling}

Since the pioneering work on plant modelling by C.T. de Wit [17], ecophysiological crop models have been extensively developed by integrating knowledge from different disciplines, such as crop physiology, micrometeorology, soil science, and computing technologies $[2,18,19]$. Now, crop models based on solid crop-physiological knowledge can quantify causality between relevant physiological processes and responses of these processes to environmental variables. Therefore, in principle, these crop models enable predictions beyond the environments in which the model parameters were derived and can reveal how G-E interactions come about [20-23]. Crop-related model input parameters are also referred to as 'genetic coefficients' because these model input parameters might be (at least partly) under genetic control. Therefore, crop modelling could be used to give suggestions for ideotype breeding [24].

However, crop models often do not consider the genetic basis of model parameters that describe genotypic differences $[9,25]$, nor do they consider how much genetic variation exists in the genetic materials available for breeding. Yin et al. $[21,26,27]$ first tried to combine crop modelling with QTL mapping using a SUCROS-type crop model. The QTL analysis was first applied to the model input traits. After the QTL analysis, the identified QTLs were then coupled to the crop model by replacing the original measured input trait values with those predicted based on the QTL effects [21]. This approach was first showcased for predicting differences in yield among relatively similar lines from a genetic population (Figure 1). They showed, however, that improved models were needed in order to make this approach really successful and robust [22]. Later, this QTL-based modelling approach was used to study specific crop traits such as leaf elongation rate in maize, flowering time, and fruit quality [28-35]. These later studies showed that this approach was robust in predicting genetic differences in bi-parental crossing populations under different conditions (in terms of vapor pressure deficit, soil moisture content, temperature, and photoperiod). However, most studies focused on specific traits, as mentioned above. The QTL-based modelling approach applied to complex traits (e.g., yield) was challenging [21,26,27,36,37], when compared with results applied to single-crop traits. The reason is that yield is much more complex considering the hierarchy from leaf photosynthesis to crop yield [38], and further improvements in the crop model were suggested by Yin and Struik [38].

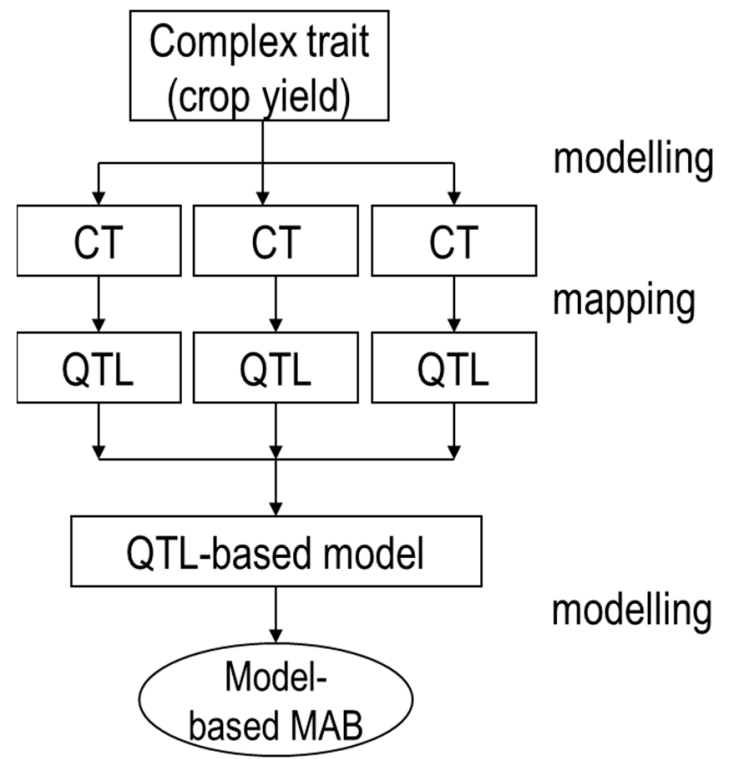

Figure 1. This is the scheme of quantitative trait locus (QTL)-based modelling approach. Photosynthesis and other traits are components that contribute to 'crop yield', and complex traits such as yield can also be dissected into component traits (CTs). CTs can be subjected to QTL analysis. With QTL 
allelic information and estimated QTL effects, model input trait values can be calculated based on the genotype and used as inputs to crop models, thus replacing original measured input trait values. This QTL-based approach can dissect complex traits (e.g., yield) into physiologically relevant component traits, then integrate effects of QTL of the component traits over time and space at whole-crop level, and in the end, predict yield of various allele combinations under different environmental conditions. Such QTL-based modelling can identify the markers that are most important for yield determination and accelerate plant breeding.

QTL-based modelling could potentially evaluate constraints in breeding due either to limited genetic variation or to correlations between the traits. QTL-based modelling could evaluate the effect of QTLs for traits at the organ level on crop yield under different environments, which could be useful in breeding for specific environments. For example, Chenu et al. [39], using the crop model APSIM-Maize, demonstrated that a QTL accelerating leaf elongation could not only increase the yield in an environment with a water deficit before flowering, but also reduce yield under terminal drought stress. QTL-based modelling could also be useful in supporting marker-assisted selection [39].

In short, QTL-based crop modelling, combining ecophysiological modelling and genetic mapping, can dissect complex yield traits into component traits, integrate effects of QTLs of the component traits over time and space at the whole-crop level, and predict the yield of various allele combinations under different environmental conditions.

\section{Application of the Modelling Approach}

\subsection{Models Can Support the Quantitative Trait Loci (QTLS) Mapping}

A pre-requisite for the proper use of phenotypic data for quantitative genetic analysis is that the phenotypic data of different genotypes should be collected under the same environmental conditions and at the same plant developmental stage. On the other hand, quantitative genetic analysis requires screening of a large population to realize the required genetic resolution based on the high power of the analyses. Complicated statistical analyses and experimental designs were often used to remove environmental errors, for example, caused by heterogeneity in the experimental field. However, for highly sensitive traits (such as photosynthesis), microclimate fluctuations can also obscure the genetic effects existing in the population. Ecophysiological models based on solid physiological knowledge could be useful tools for standardizing the measurements [40]. Using model-based standardization, several QTLs related to photosynthesis were found under field conditions. Ecophysiological models can thus play a role in improving the quality of data on traits that are difficult to phenotype. Another example was reported by Yin et al. [26], who mapped specific leaf area (SLA) in a barley recombinant inbred population. After adjusting SLA values measured at the same chronological time to values measured at the same physiological age, the effect on SLA from the denso gene was no longer significant. The effect of the denso gene detected at the same chronological time was therefore the consequence of its direct effect on flowering time. An ecophysiological model can thus indeed assist QTL analysis by removing either environmental noise or indirect effects from other traits.

\subsection{Models Can Dissect Complex Traits into Physiological Components}

Physiological modelling can dissect complex traits (e.g., photosynthesis or yield) into physiological component traits. For example, in the study of Gu et al. [41], a photosynthesis model was used to dissect photosynthesis into: (1) stomatal conductance $g_{\mathrm{s}}$, (2) mesophyll conductance $g_{\mathrm{m}}$, and (3) electron transport capacity and Rubisco carboxylation capacity. $\mathrm{Gu}$ et al. [36], using the crop model GECROS, connected and dissected yield trait into seven physiological input parameters (i.e., seed dry weight, $S_{\mathrm{w}}$; seed $\mathrm{N}$ concentration, $n_{\mathrm{so}}$; maximum plant height, $H_{\mathrm{max}}$; minimum days for vegetative growth phase, $m_{\mathrm{v}} ;$ minimum days for reproductive (seed fill) phase, $m_{\mathrm{R}}$; specific leaf area constant, $S_{\text {la }}$; total crop $\mathrm{N}$ uptake at crop maturity, $N_{\max }$ ). By dissecting complex traits into physiologically meaningful component traits, it is possible to assess genetic variation for each component trait and evaluate its relative importance by sensitive analyses or regression analyses. For 
example, by regression analysis, genetic variation in light-saturated photosynthesis and transpiration efficiency was found to be mainly associated with variation in $g_{\mathrm{s}}$ and $g_{\mathrm{m}}$ [41]. Similarly, Prudent et al. [35], combining an ecophysiological modelling and QTL analysis, identified key elementary processes and genetic factors underlying tomato fruit sugar concentration. Dingkuhn et al. [42,43] showed that ecophysiological models can assist phenotyping and genome-wide association studies by dissecting early vigour, phenology, and spikelet sterility into their components. All these results show that the physiological model can be helpful to prioritize target traits for breeding, although its possible impact remains to be validated through actual breeding and field testing.

\subsection{Models Can Integrate and Project Single-Organ Level Genetic Variation to Crop Level}

Modelling can not only dissect complex traits into relevant physiological components but also integrate the effects of QTLs of the component traits over time and space and predict complex traits at the whole-crop level of various genetic make-ups under different environmental conditions. This could be useful for evaluating the effect of changes in a single-trait or single-trait-related QTL on a crop level, while keeping other traits constant to avoid the confounding effects from other physiological processes, which is not plausible in a 'real' experiment. For example, as stated earlier, improving photosynthesis is generally thought to be crucial for improving plant production, but often no correlation or even negative correlations between photosynthesis and plant production were observed [36,44-47]. The reason for this discrepancy could be that plants differed genetically in many aspects other than photosynthesis. Gu et al. [36] used the crop model GECROS and found that the natural genetic variation in leaf photosynthesis within their experimental materials would result in equivalent differences in production when scaled up to the crop level. Integration and upscaling can also help evaluate the impacts of QTLs for a specific organ-level trait at the crop level in a different environment. Chenu et al. [39], using the crop model APSIM-Maize, evaluated the effects of a QTL which accelerated leaf elongation on maize yield. This QTL could cause a yield increase in an environment with a water deficit before flowering but reduced yield under terminal drought stress. This information could be used in breeding for specific environments or for facing the challenges caused by climate change. By incorporating a genome-wide association into an ecophysilogical simulation model, Kadam et al. [8] showed that the model has the potential to use single-environment information to predict the yield of genotypes under different environments. Most importantly, the feature of integration could allow for designing ideotypes of various genetic make-ups underlying physiological processes. Based on the genetic variation and resulting QTLs for each physiological component in photosynthesis, it was shown that the ideotype for leaf-level photosynthesis and TE could potentially be improved by $17.0 \%$ and $25.1 \%$, respectively [ 41$]$.

\subsection{QTL-Based Modelling Can Quantify Constraints in Breeding}

Model simulation could inspire breeders. However, Stam [9] and Picheny et al. [25], from a geneticist's perspective, expressed their concerns that the ignorance of inheritability of model input traits is a major constraint for breeders in adopting the results of modelbased approaches. Often in ideotype design by modelling, modellers implicitly assume that plant traits can be combined at will into a single genotype. Such an unrealistic practice ignores the possible existence of constraints, feedback mechanisms, and correlations among traits. By integrating crop modelling with genetics-QTL-based modelling-it is possible to evaluate constraints in breeding either due to limited genetic variation or to correlations. For example, trade-offs were shown between improving photosynthesis and TE either due to tight linkage or to the pleiotropic effects of QTLs related to $g_{\mathrm{m}}$ and $g_{\mathrm{s}}$ [41]. If the linkage between $g_{\mathrm{m}}$ and $g_{\mathrm{s}}$ or co-location of QTLs of $g_{\mathrm{m}}$ and $g_{\mathrm{s}}$ could be broken, the virtual ideotype could have both improved photosynthesis and TE. The quantitative importance of breaking this linkage could be used together with the insights of geneticists about chances 
of success in guiding decisions in breeding programs, thus strengthening the scientific basis for the breeding program design.

\subsection{QTL-Based Modelling Can Assist Marker-Assisted Selection}

Marker-assisted selection (MAS), combined with conventional breeding approaches, has been used to effectively integrate major genes or QTLs with a significant effect into widely grown varieties [48]. The use of cost-effective DNA markers and a MAS strategy can provide opportunities for breeders to develop high-yielding, stress-tolerant, and betterquality rice cultivars [49]. For example, pyramiding different resistance genes using MAS provided opportunities to breeders to develop broad-spectrum resistance against diseases and insects [50]. This thesis also showed that the existing GECROS model can be a useful tool in enhancing marker-assisted breeding through a model-based ideotype design [36]. Using the principles for QTL-based modelling, as defined earlier [20,21], marker-based crop modelling was performed to rank the markers identified for various yield-determining physiological traits that are input parameters of GECROS [36]. Such an analysis detected markers that breeders can prioritize in their MAS programmes for specific environments. Compared with identification of markers through multiple regression for yield per se, the model-based approach identified additional QTLs and could be complementary to the analysis of yield per se.

\section{Future Prospects of Integration of Crop Modelling and Plant Genetics}

Generally, QTLs can be identified for a set of physiological parameters associated with leaf photosynthesis, phenological development rates, morphological traits, etc. These traits could be used as input parameters for the crop model. With their marker/QTL-based estimates as input to the model, the QTL effects for traits, typically at the single-organ level over a short time scale, were projected for their impact on crop growth during the whole growing season in the field. In this way, the information from functional genomics can be brought up to the crop level via modelling. For example, in the studies of $\mathrm{Gu}$ et al. [36,40,41,51], leaf photosynthesis was analyzed and dissected into biophysical and biochemical component traits by a detailed photosynthesis model, and then scaled up to the crop level with the GECROS model, which uses the concept of carbon-nitrogen interactions for balanced modelling of crop growth. This analysis showed that the modelling strategy can promote communication across scales from the level of leaves, from the canopy to the crop level.

Systems simulation modelling has long been suggested as a powerful tool that can assist in understanding crop yield formation, crop improvement programmes [2]. However, modelling studies at the crop level using some knowledge of fundamental plant biology (biochemistry, genomics) are currently still sporadic [38]. Some model algorithms are based on untested or empirical hypotheses, or even missing. For example, a better algorithm for the spikelet number of rice is needed when applying the model to drought environments, when high tissue organ temperature and high spikelet sterility can be expected [52]. This indicates that model components related to sink formation still need to be improved, especially for predictions for stressed environments. Besides, there are inherent spatial variations between different crop fields, which limits the application of crop modelling in predicting yields of large areas [53]. Nowadays, large amounts of data from remote sensing and high throughput phenotyping, as well as modern statistical methods, such as machine learning, deep learning, etc., provide opportunities to better capture the spatial and temporal variations when crop modelling is coupled with the emerging data science [54-57], which will strengthen the future application of crop modelling [53].

The QTL-based modelling approach could be further expanded. Gene-based crop modelling has already practiced by White and Hoogenboom [10], Messina et al. [58], and White et al. [12] but only on an empirical basis. The fast development of genomics with second-generation genome sequencing and genome-wide association studies may enhance opportunities for developing gene-based modelling. The advance of transcriptomics, 
proteomics, metabolomics, and phenomics may enhance the link between genome data, metabolic pathways and processes, physiological component processes, and crop yield and production. Accordingly, different temporal, spatial and structural scales are required for different components, pathways, and processes of the model [38]. In the end, an approach such as 'crop systems biology' [38] should enable in the silico assessment of crop response to genetic fine-tuning under defined environmental scenarios, thereby providing a powerful tool that can support breeding for complex crop traits.

Funding: This research was funded by the National Natural Science Foundation of China (31872853) and the Priority Academic Program Development of Jiangsu Higher Education Institutions (PAPD).

Institutional Review Board Statement: Not applicable.

Informed Consent Statement: Not applicable.

Conflicts of Interest: The author declares no conflict of interest.

\section{References}

1. Wollenweber, B.; Porter, J.R.; Lübberstedt, T. Need for multidisciplinary research towards a second green revolution. Curr. Opin. Plant Biol. 2005, 8, 337-341. [CrossRef]

2. Loomis, R.S.; Rabbinge, R.; Ng, E. Explanatory models in crop physiology. Annu. Rev. Plant Biol. 1979, 30, 339-367. [CrossRef]

3. Whisler, F.; Acock, B.; Baker, D.; Fye, R.; Hodges, H.; Lambert, J.; Lemmon, H.; McKinion, J.; Reddy, V. Crop Simulation Models in Agronomic Systems. Adv. Agron. 1986, 40, 141-208.

4. Shorter, R.; Lawn, R.J.; Hammer, G.L. Improving genotypic adaptation in crops-A role for breeders, physiologists and modellers. Exp. Agric. 1991, 27, 155-175. [CrossRef]

5. Boote, K.J.; Jones, J.W.; Pickering, N.B. Potential uses and limitations of crop models. Agron. J. 1996, 88, 704-716. [CrossRef]

6. Boote, K.J.; Kropff, M.J.; Bindraban, P.S. Physiology and modelling of traits in crop plants: Implications for genetic improvement. Agric. Syst. 2001, 70, 395-420. [CrossRef]

7. Miflin, B. Crop improvement in the 21st century. J. Exp. Bot. 2000, 51, 1-8. [CrossRef] [PubMed]

8. Kadam, N.N.; Jagadish, S.V.K.; Struik, P.C.; van der Linden, C.G.; Yin, X. Incorporating genome-wide association into ecophysiological simulation to identify markers for improving rice yields. J. Exp. Bot. 2019, 70, 2575-2586. [CrossRef]

9. Stam, P. Crop physiology, QTL analysis and plant breeding. In Inherent Variation in Plant Growth: Physiological Mechanisms and Ecological Consequences; Lambers, H., Poorter, H., van Vuuren, M.M.I., Eds.; Backhuys Publishers: Leiden, The Netherlands, 1998; pp. 429-440.

10. White, J.W.; Hoogenboom, G. Simulating effects of genes for physiological traits in a process-oriented crop model. Agron. J. 1996, 88, 416-422. [CrossRef]

11. Mavromatis, T.; Boote, K.; Jones, J.; Irmak, A.; Shinde, D.; Hoogenboom, G. Developing genetic coefficients for crop simulation models with data from crop performance trials. Crop Sci. 2001, 41, 40-51. [CrossRef]

12. White, J.W.; Herndl, M.; Hunt, L.; Payne, T.S.; Hoogenboom, G. Simulation-based analysis of effects of and loci on flowering in wheat. Crop Sci. 2008, 48, 678-687. [CrossRef]

13. Tardieu, F. Any trait or trait-related allele can confer drought tolerance: Just design the right drought scenario. J. Exp. Bot. 2011, 63, 25-31. [CrossRef]

14. Rebetzke, G.J.; Condon, A.G.; Richards, R.A.; Farquhar, G.D. Selection for reduced carbon isotope discrimination increases aerial biomass and grain yield of rainfed bread wheat. Crop Sci. 2002, 42, 739-745. [CrossRef]

15. Condon, A.G.; Richards, R.A.; Rebetzke, G.J.; Farquhar, G.D. Breeding for high water-use efficiency. J. Exp. Bot. 2004, 55, 2447-2460. [CrossRef]

16. Blum, A. Drought resistance, water-use efficiency, and yield potential—Are they compatible, dissonant, or mutually exclusive? Aust. J. Agric. Res. 2005, 56, 1159-1168. [CrossRef]

17. de Wit, C.T. Potential photosynthesis of crop surfaces. Neth. J. Agric. Sci. 1959, 7, 141-149. [CrossRef]

18. Bouman, B.; Van Keulen, H.; van Laar, H.; Rabbinge, R. The 'School of de Wit' crop growth simulation models: A pedigree and historical overview. Agric. Syst. 1996, 52, 171-198. [CrossRef]

19. McCown, R.L.; Hammer, G.L.; Hargreaves, J.N.G.; Holzworth, D.P.; Freebairn, D.M. APSIM: A novel software system for model development, model testing and simulation in agricultural systems research. Agric. Syst. 1996, 50, 255-271. [CrossRef]

20. Yin, X.; Kropff, M.J.; Goudriaan, J.; Stam, P. A model analysis of yield differences among recombinant inbred lines in barley. Agron. J. 2000, 92, 114-120. [CrossRef]

21. Yin, X.; Chasalow, S.D.; Dourleijn, C.J.; Stam, P.; Kropff, M.J. Coupling estimated effects of QTLs for physiological traits to a crop growth model: Predicting yield variation among recombinant inbred lines in barley. Heredity 2000, 85, 539-549. [CrossRef] [PubMed]

22. Yin, X.; Struik, P.C.; Kropff, M.J. Role of crop physiology in predicting gene-to-phenotype relationships. Trends Plant Sci. 2004, 9 , 426-432. [CrossRef] [PubMed] 
23. Sinclair, T.R. Challenges in breeding for yield increase for drought. Trends Plant Sci. 2011, 16, 289-293. [CrossRef]

24. Haverkort, A.J.; Kooman, P.L. The use of systems analysis and modelling of growth and development in potato ideotyping under conditions affecting yields. Euphytica 1997, 94, 191-200. [CrossRef]

25. Picheny, V.; Casadebaig, P.; Trepos, R.; Faivre, R.; Da Silva, D.; Vincourt, P.; Costes, E. Using numerical plant models and phenotypic correlation space to design achievable ideotypes. Plant Cell Environ. 2017, 40, 1926-1939. [CrossRef] [PubMed]

26. Yin, X.; Kropff, M.J.; Stam, P. The role of ecophysiological models in QTL analysis: The example of specific leaf area in barley. Heredity 1999, 82, 415-421. [CrossRef]

27. Yin, X.; Stam, P.; Dourleijn, C.J.; Kropff, M.J. AFLP mapping of quantitative trait loci for yield-determining physiological characters in spring barley. Theor. Appl. Genet. 1999, 99, 244-253. [CrossRef]

28. Reymond, M.; Muller, B.; Leonardi, A.; Charcosset, A.; Tardieu, F. Combining quantitative trait loci analysis and an ecophysiological model to analyze the genetic variability of the responses of maize leaf growth to temperature and water deficit. Plant Physiol. 2003, 131, 664-675. [CrossRef] [PubMed]

29. Quilot, B.; Wu, B.H.; Kervella, J.; Génard, M.; Foulongne, M.; Moreau, K. QTL analysis of quality traits in an advanced backcross between Prunus persica cultivars and the wild relative species P. davidiana. Theor. Appl. Genet. 2004, 109, 884-897. [CrossRef]

30. Nakagawa, H.; Yamagishi, J.; Miyamoto, N.; Motoyama, M.; Yano, M.; Nemoto, K. Flowering response of rice to photoperiod and temperature: A QTL analysis using a phenological model. Theor. Appl. Genet. 2005, 110, 778-786. [CrossRef]

31. Quilot, B.; Kervella, J.; Génard, M.; Lescourret, F. Analysing the genetic control of peach fruit quality through an ecophysiological model combined with a QTL approach. J. Exp. Bot. 2005, 56, 3083-3092. [CrossRef]

32. Yin, X.; Struik, P.C.; van Eeuwijk, F.A.; Stam, P.; Tang, J. QTL analysis and QTL-based prediction of flowering phenology in recombinant inbred lines of barley. J. Exp. Bot. 2005, 56, 967-976. [CrossRef]

33. Uptmoor, R.; Schrag, T.; Stützel, H.; Esch, E. Crop model based QTL analysis across environments and QTL based estimation of time to floral induction and flowering in Brassica oleracea. Mol. Breed. 2008, 21, 205-216. [CrossRef]

34. Bertin, N.; Martre, P.; Génard, M.; Quilot, B.; Salon, C. Under what circumstances can process-based simulation models link genotype to phenotype for complex traits? Case-study of fruit and grain quality traits. J. Exp. Bot. 2010, 61, 955-967. [CrossRef] [PubMed]

35. Prudent, M.; Lecomte, A.; Bouchet, J.P.; Bertin, N.; Causse, M.; Génard, M. Combining ecophysiological modelling and quantitative trait locus analysis to identify key elementary processes underlying tomato fruit sugar concentration. J. Exp. Bot. 2011, 62, 907-919. [CrossRef] [PubMed]

36. Gu, J.; Yin, X.; Zhang, C.; Wang, H.; Stuik, P.C. Linking ecophysiological modelling with quantitative genetics to support marker-assisted crop design for improved rice (Oryza sativa L.) yields under drought stress. Ann. Bot. 2014, 114, 499-511. [CrossRef] [PubMed]

37. Muller, B.; Martre, P. Plant and crop simulation models: Powerful tools to link physiology, genetics, and phenomics. J. Exp. Bot. 2019, 9, 2339-2344. [CrossRef] [PubMed]

38. Yin, X.; Struik, P.C. Applying modelling experiences from the past to shape crop systems biology: The need to converge crop physiology and functional genomics. New Phytol. 2008, 179, 629-642. [CrossRef] [PubMed]

39. Chenu, K.; Chapman, S.C.; Tardieu, F.; McLean, G.; Welcker, C.; Hammer, G.L. Simulating the yield Impacts of organ-level quantitative trait loci associated with drought response in maize: A "gene-to-phenotype" modeling approach. Genetics 2009, 183, 1507-1523. [CrossRef]

40. Gu, J.; Yin, X.; Struik, P.C.; Stomph, T.J.; Wang, H. Using chromosome introgression lines to map quantitative trait loci for photosynthesis parameters in rice (Oryza sativa L.) leaves under drought and well-watered field conditions. J. Exp. Bot. 2012, 63, 455-469. [CrossRef]

41. Gu, J.; Yin, X.; Stomph, T.J.; Wang, H.; Struik, P.C. Physiological basis of genetic variation in leaf photosynthesis among rice (Oryza sativa L.) introgression lines under drought and well-watered conditions. J. Exp. Bot. 2012, 63, 5137-5153. [CrossRef]

42. Dingkuhn, M.; Pasco, R.; Pasuquin, J.M.; Damo, J.; Soulié, J.C.; Raboin, L.M.; Dusserre, J.; Sow, A.; Manneh, B.; Shrestha, S.; et al. Crop-model assisted phenomics and genome-wide association study for climate adaptation of indica rice. 1. Phenology. J. Exp. Bot. 2017, 68, 4369-4388. [CrossRef]

43. Dingkuhn, M.; Pasco, R.; Pasuquin, J.M.; Damo, J.; Soulié, J.C.; Raboin, L.M.; Dusserre, J.; Sow, A.; Manneh, B.; Shrestha, S.; et al. Crop-model assisted phenomics and genome-wide association study for climate adaptation of indica rice. 2. Thermal stress and spikelet sterility. J. Exp. Bot. 2017, 68, 4389-4406. [CrossRef]

44. Evans, L.T.; Dunstone, R.L. Some physiological aspects of evolution in wheat. Aust. J. Biol. Sci. 1970, 23, 725-742. [CrossRef]

45. Teng, S.; Qian, Q.; Zeng, D.; Kunihiro, Y.; Fujimoto, K.; Huang, D.; Zhu, L. QTL analysis of leaf photosynthetic rate and related physiological traits in rice (Oryza sativa L.). Euphytica 2004, 135, 1-7. [CrossRef]

46. Zhao, X.Q.; Xu, J.L.; Zhao, M.; Lafitte, R.; Zhu, L.; Fu, B.Y.; Gao, Y.M.; Li, Z.K. QTLs affecting morph-physiological traits related to drought tolerance detected in overlapping introgression lines of rice (Oryza sativa L.). Plant Sci. 2008, 174, 618-625. [CrossRef]

47. Jahn, C.E.; Mckay, J.; Mauleon, R.; Stephens, J.; McNally, K.L.; Bush, D.R.; Leung, H.; Leach, J.E. Genetic variation in biomass traits among 20 diverse rice varieties. Plant Physiol. 2011, 155, 157-168. [CrossRef] [PubMed]

48. Jena, K.; Mackill, D. Molecular markers and their use in marker-assisted selection in rice. Crop Sci. 2008, 48, 1266-1276. [CrossRef]

49. Collard, B.C.Y.; Mackill, D.J. Marker-assisted selection: An approach for precision plant breeding in the twenty-first century. Philos. Trans. R. Soc. B Biol. Sci. 2008, 363, 557-572. [CrossRef] 
50. Huang, N.; Angeles, E.; Domingo, J.; Magpantay, G.; Singh, S.; Zhang, G.; Kumaravadivel, N.; Bennett, J.; Khush, G. Pyramiding of bacterial blight resistance genes in rice: Marker-assisted selection using RFLP and PCR. Theor. Appl. Genet. 1997, 95, 313-320. [CrossRef]

51. Gu, J.; Yin, X.; Stomph, T.J.; Struik, P.C. Can exploiting natural genetic variation in leaf photosynthesis contribute to increasing rice productivity? A simulation analysis. Plant Cell Environ. 2014, 37, 22-34. [CrossRef]

52. Jagadish, S.V.K.; Craufurd, P.Q.; Wheeler, T.R. High temperature stress and spikelet fertility in rice (Oryza Sativa L.). J. Exp. Bot. 2007, 58, 1627-1635. [CrossRef] [PubMed]

53. Yin, X.; Struik, P.C.; Goudriaan, J. On the needs for combining physiological principles and mathematics to improve crop models. Field Crop Res. 2021, 271, 108254. [CrossRef]

54. van Klompenburg, T.; Kassahun, A.; Catal, C. Crop yield prediction using machine learning: A systematic literature review. Comput. Electron. Agric. 2020, 177, 105709. [CrossRef]

55. McCormick, R.F.; Truong, S.K.; Rotundo, J.; Gaspar, A.P.; Kyle, D.; van Eeuwijk, F.; Messina, C.D. Intercontinental prediction of soybean phenology via hybrid ensemble of knowledge-based and data-driven models. In Silico Plants 2021, 3, diab004. [CrossRef]

56. Shahhosseini, M.; Hu, G.; Huber, I.; Archontoulis, S.V. Coupling machine learning and crop modeling improves crop yield prediction in the US corn belt. Sci. Rep. 2021, 11, 1606. [CrossRef]

57. Paudel, D.; Boogaard, H.; de Wit, A.; Janssen, S.; Osinga, S.; Pylianidis, C.; Athanasiadis, I.N. Machine learning for large-scale crop yield forecasting. Agric. Syst. 2021, 187, 103016. [CrossRef]

58. Messina, C.; Jones, J.; Boote, K.; Vallejos, C. A gene-based model to simulate soybean development and yield responses to environment. Crop Sci. 2006, 46, 456-466. [CrossRef] 